\title{
Niche segregation among three sympatric species of squirrels inhabiting a lowland dipterocarp forest, Peninsular Malaysia
}

\author{
Saiful Arif Abdullah ${ }^{1}$, Norma Yusoff-Rashid ${ }^{2}$ and Azarae Hj. Idris $^{3}$ \\ ${ }^{1}$ Institute for Environment and Development (LESTARI), Universiti Kebangsaan Malaysia, Bangi \\ 43600 Selangor Darul Ehsan, Malaysia \\ ${ }^{2,3}$ Department of Zoology, Institute of Biological Science, Faculty of Science, University of Malaya, \\ 50603 Kuala Lumpur, Malaysia
}

\begin{abstract}
Niche segregation among three sympatric species of squirrels, Callosciurus notatus, C. caniceps and Sundasciurus lowii inhabiting a lowland dipterocarp forest was studied in the Ulu Gombak Forest Reserve, Selangor Darul Ehsan, Malaysia. Diurnal activity of the three species had two peaks. Sundasciurus lowii and $C$. caniceps were more restricted in vertical space, concentrated mainly at lower tree heights, whereas $C$. notatus was slightly less restricted. Sundasciurus lowii were more selective in their diet: bark was the main food item. The two Callosciurus spp. took a variety of food items, although fruit was the major component. The niche breadth values in diurnal activity patterns, vertical space uses, and food preferences revealed that $C$. notatus was a generalist compared with the other two species. Differences in selection of tree species rather than food item may be the main factors that determine niche occupancy for the three species of squirrels in the study area.
\end{abstract}

Key words: niche breadth, niche overlap, squirrel, sympatric, tropical rain forest.

Differential use of resources by ecologically similar species plays an important role in their coexistence (Schoener 1974). Pianka (1973) proposed three basic niche dimensions in which animals can partition environmental resources: temporally (time), spatially (space) and trophically (food).

In temperate regions, studies of niche segregation among ecologically similar species have revealed that multiple factors influence the coexistence of species. Several studies concluded that the spacing among interspecific individuals was best explained by differences in habitat selection (Armitage and Harris 1982; Lacher and Alho 1989; Mullican and Baccus 1990; Riege 1991). On the other hand, some authors argued that intraspecific and interspecific competition played important roles in determining coexistence of species (Sheppard 1971; Adler 1985; Ducey et al. 1994). In some cases, both interactions and differences in habitat preferences were important in maintaining habitat separation between two species (Douglass 1976). In addition, studies of local distribution of Apodemus sylvaticus and $A$. flavicolis showed that the segregation of these two field mice was related to the distribution of

'E-mail: saiful@pkrisc.cc.ukm.my 
preferred food types (Angelstam et al. 1987)

The tropical rain forest harbors a great diversity of animal species. Perhaps more so than in temperate regions, more than two ecologically similar species can coexist in one area because of complex forest structures. Given this complexity, a variety of factors including habitat preference and behavioral interactions may determine the coexistence of similar species in one area. Numerous tree and gliding squirrel species (14 diurnal and 11 nocturnal species) inhabit the tropical rain forests of Peninsular Malaysia (Medway 1983). Previous studies have proposed that interspecific differences in activity patterns, preferred food items and vertical space use determine the coexistence of squirrel species in tropical areas (MacKinnon 1978; Emmons 1980; Whitten 1981).

In the current study we investigated the factors influencing the segregation of sympatric squirrel species in Peninsular Malaysia.

\section{Study area}

Studies were conducted in a lowland dipterocarp forest of the Field Study Center, University of Malaya, Ulu Gombak, Selangor Darul Ehsan, Malaysia ( $\left.3^{\circ} 21^{\prime} \mathrm{N} 101^{\circ} 45^{\prime} \mathrm{E}\right)$. Generally, the topography is undulating terrain about $240 \mathrm{~m}$ above sea level, part of the southern area of the Main Range.

Sungai Gombak (Gombak River) flows through the study area and many seasonal streams flow from the adjacent highlands to the river. The vegetation cover is typical of the tropical rain forest, dominated by dipterocarps. The area had been logged twice in the past, and now is characterized by trees of small diameter in various growth stages.

We identified five species of squirrel inhabiting the study area: four arboreal squirrels, Callosciurus notatus, C. caniceps, C. nigrovittatus and Sundasciurus lowii and a terrestrial squirrel, Lariscus insignis. For this study, three arboreal squirrels were chosen, $C$. notatus, $C$. caniceps and $S$. lowii because they are the most common species in the study area. In addition, preliminary study revealed that their population sizes were high compared with the other two species.

In the study area, Callosciurus notatus (Plantain squirrel) is mostly found in areas of low tree density (Tamura and Yong 1993). In Peninsular Malaysia, this medium sized species (160-259 $\mathrm{g}$ body weight) is common in the southern and central states, becoming rare towards the north (Medway 1983). Callosciurus caniceps (Gray-bellied squirrel; 165-315 g body weight) is found in areas dominated by shrubs (Tamura and Yong 1993) and is common in the northern and central states of Peninsular Malaysia, (Medway 1983). Sundasciurus lowii (Low's squirrel) is a small brown squirrel (65-69 $\mathrm{g}$ body weight) found in the lowlands and foothills of mainland Peninsular Malaysia (Medway 1983).

\section{Methods}

We investigated diurnal activity patterns, vertical space use, and food item selection of the three arboreal squirrels by direct observation. Records of vertical space use and food items were collected randomly for the three species, 15 days/month from September 1992 to October 1993. All field observations were carried out using binoculars $(7 \times 35 \mathrm{E}$ NIKON) while walking slowly along a $1.9 \mathrm{~km}$ census route, covering approximately 20 ha of secondary 
forest. Most observations were made from 0700 to $0900 \mathrm{hrs}$ and 1700 to $1900 \mathrm{hrs}$ because squirrels were most active during these two time periods (Tamura 1993). In addition, diurnal activities were investigated between 0700 and $1900 \mathrm{hrs}, 10$ days/month throughout the study period, to obtain data on the relative level of activity throughout the day for each species. Once the squirrels were spotted, focal sampling (Martin and Bateson 1987) was used until the subject moved out of sight. This was recorded as one sighting. The time of each sighting was recorded, and the animal's activity was classified in one of the following eight categories; feeding, foraging, traveling, resting, alert behavior or mobbing, grooming, nest building, and social interaction.

Vertical space use was based on the height of squirrels observed above the ground. Height was estimated visually and then was divided into eight levels; ground, zero to five meters, six-10 m, 11-15 m, 16-20 m, 21-25 m, 26-30 m and above $30 \mathrm{~m}$. Data on food items were also obtained when feeding behavior of squirrels was observed. Food items were classified into five categories: fruit, flower, bark, leaf and other items. The last category included arthropods, fungi, and mosses, which could not be identified through direct observation. All the trees, which had their reproductive parts (fruits, flowers and leaves) and bark consumed by the squirrel were tagged for later identification.

To determine how the coexisting species segregate across resource dimensions, two indices, niche breadth (B) and niche overlap $\left(\alpha_{i j}\right)$, were calculated based on the formulas in Feisinger et al. (1981) and Slobodchikoff and Schulz (1980), respectively.

For niche breadth value, $(\mathrm{B})=1 / \Sigma P_{i}^{2}$

where, $P_{i}$ represents the proportion of sightings of a species found in $i$ th unit of the resource set. $\mathrm{B}$ ranges from 1.0 when a species uses one resource exclusively, to $n$ when the species use all the resources in equal proportion (Feisinger at al. 1981).

For niche overlap value, $\left(\alpha_{i j}\right)=\Sigma \boldsymbol{P}_{i h} \boldsymbol{P}_{j h} / \sqrt{ }\left(\Sigma \boldsymbol{P}_{i h}{ }^{2}\right) \sqrt{ }\left(\Sigma \boldsymbol{P}_{j h}{ }^{2}\right)$

where, $a_{i j}$ represents the niche overlap of species $i$ over species $j$.

$P_{i h}$ and $P_{j h}$ represent the proportions of sightings of each species in the $h_{t h}$ unit of a certain resource dimension and $a_{i j}$ values range from 0 (no overlap) to 1.0 (complete overlap).

\section{Results}

\section{Diurnal activity patterns}

All three sympatric squirrel species showed generally bimodal activity patterns (Fig. 1). The total number of sightings were 263, 229, and 129 for $C$. notatus, C. caniceps and $S$. lowii, respectively. In all three species, there were two peaks of activity, during the early morning and the late evening. Plantain squirrels (C. notatus) were very active at $0700 \mathrm{hrs,}$ with activity levels falling thereafter until $1100 \mathrm{hrs}$. Activity remained consistently low from 1100 to $1500 \mathrm{hrs}$. At $1600 \mathrm{hrs}$, activity began picking up again and reached a peak at 1800 hrs.

The peak activity for gray-bellied squirrels (C. caniceps) occurred from 0700 to $0800 \mathrm{hrs}$. Thereafter, activity began to decrease and sustained low levels from 0800 to $1500 \mathrm{hrs}$. As in C. notatus, activity began picking up at $1600 \mathrm{hrs}$ and reached a second peak at $1800 \mathrm{hrs}$. In 
Low's squirrels (S. lowii), activity was high at $0700 \mathrm{hrs,}$ as in the two Callosciurus spp. and began to decline at $0800 \mathrm{hrs}$. Activity remained constant until $1000 \mathrm{hrs}$ and decreased rapidly at $1100 \mathrm{hrs}$. At $1500 \mathrm{hrs}$ the activity began to increase until reaching a peak at 1600 hrs and again declining at $1700 \mathrm{hrs}$.

Patterns of diurnal activity overlapped extensively between the three species. The niche overlap values between $C$. caniceps and $S$. lowii $\left(a_{i j}=0.92\right)$ and between $C$. notatus and $S$. lowii $\left(a_{i j}=0.91\right)$ were similar, whereas that between $C$. notatus and $C$. caniceps $\left(a_{i j}=0.85\right)$ was slightly lower. However, the niche breadth values showed clear proportional differences

(a) Callosciunus notatus $n=263$

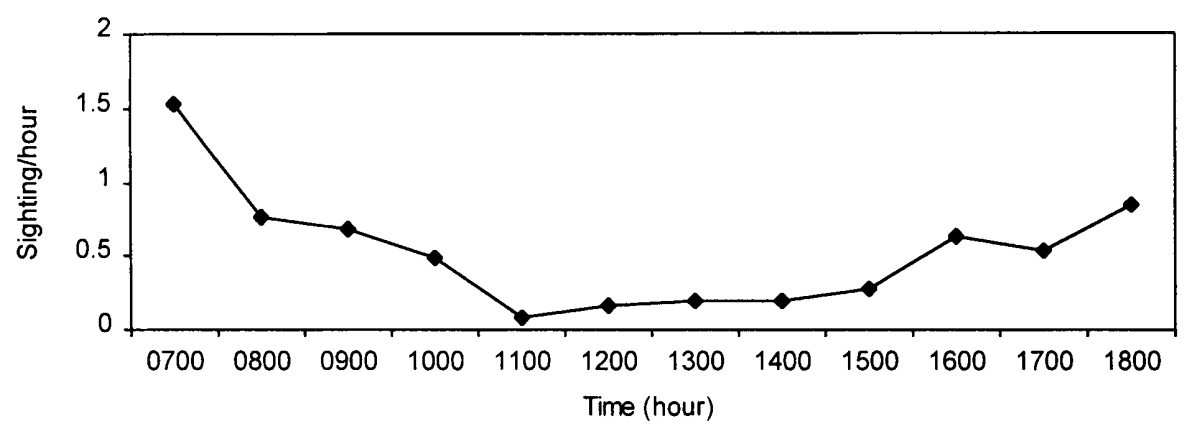

(b) Callosciurus caniceps $\quad n=229$



(c) Sundasciurus lowi $n=129$



Fig. 1. Diurnal activity patterns of three sympatric squirrel species. 
in activity. Niche breadth value was highest for $S$. lowii $(\mathrm{B}=7.40)$, followed by $C$. caniceps $(B=6.99)$ and $C$. notatus $(B=4.63)$. Based on this measure, the daily activities of $C$. notatus were more restricted than those of the other species.

\section{Vertical space use}

We recorded 348 sightings of $C$. notatus, 276 sightings of $C$. caniceps and 180 sightings of S. lowii.

Callosciurus notatus was frequently observed at the $6-10 \mathrm{~m}$ level and avoided the ground. It was very rarely seen above 20 meters, and other height categories were moderately used (Fig. 2a). Callosciurus caniceps used height levels of $0-5 \mathrm{~m}$ and 6-10 $\mathrm{m}$ extensively and was also observed on the ground (Fig. 2b). The space 11-15 $\mathrm{m}$ above ground was moderately used and less than $10 \%$ of sightings were recorded for the remaining height levels, a lower frequency than that recorded for C. notatus (Fig. $2 \mathrm{a}$ and $2 \mathrm{~b}$ ). In $S$. lowii, more than $50 \%$ of the sightings were recorded at $0-5 \mathrm{~m}$ height, whereas the space $6-10 \mathrm{~m}$ above ground was used moderately and the other height levels totaled less than 10\% use (Fig. 2c).

Although niche overlap values $\left(a_{i j}\right)$ show that there was extensive overlap between $C$. notatus and $C$. caniceps $\left(a_{i j}=0.96\right)$, and between $C$. notatus and $S$. lowii $\left(a_{i j}=0.88\right)$ there were significant differences in vertical space use $\left(C\right.$. notatus versus $C$. caniceps: $\chi^{2}=19.9$, $d f=4, P<0.01 ; C$. notatus versus $S$. lowii: $\left.\chi^{2}=51.2, d f=3, P<0.005\right)$. However, the overlap between $C$. caniceps and $S$. lowii was lower $\left(\alpha_{i j}=0.45\right)$, and the frequencies of use by the two species at each height level differed significantly $\left(\chi^{2}=9.6, d f=3, P<0.01\right)$. Niche breadth values revealed that $C$. notatus was slightly less selective in the use of vertical space $(\mathrm{B}=4.15)$ than either $C$. caniceps $(\mathrm{B}=3.44)$ or $S$. lowii $(\mathrm{B}=2.78)$.

\section{Food items and tree species}

Relative importance of food items in the diet was determined by the proportion of sightings during which squirrels fed on identifiable items. Callosciurus notatus and $C$. caniceps used a variety of items, e.g. all reproductive parts (fruits, leaves and flowers) and bark of plants (Fig. 3a and 3b). For C. notatus, fruit and bark comprised a major portion of their diet while flowers, leaves and other items were consumed less frequently (Fig. 3a). Bark was much less important in the diet of $C$. caniceps, which often consumed leaves (Fig. 3b). Fruits made up the largest proportion of the diet of $C$. caniceps (Fig. 3b). Like $C$. notatus, S. lowii also preferred bark and fruits (Fig. 3c). However, the proportion of bark in their diet was relatively higher than that of fruits (Fig. 3c).

Niche overlap values showed extensive overlap between $C$. notatus and $C$. caniceps $\left(\alpha_{i j}\right.$ $=0.84$ ). For $S$. lowii, although no feeding records were collected for flowers and leaves (Fig. $3 c)$, the $a_{i j}$ revealed extensive overlap between this species and the two Callosciurus spp. Niche overlap values between $S$. lowii and the other two Callosciurus spp. were higher with C. notatus $\left(a_{i j}=0.99\right)$ than with $C$. caniceps $\left(a_{i j}=0.78\right)$.

The proportionate use of food items showed that the diet composition differed only slightly between species, and was reflected in the measures of dietary niche breadth, $B=3.47$ for $C$. caniceps, $\mathrm{B}=2.86$ for $C$. notatus and $\mathrm{B}=2.74$ for $S$. lowii.

Although the niche overlap values for food item categories between species were very high, there was a great difference in the numbers of plant species used by the sympatric squirrels. A total of 16 identified plant species from 11 families (Table 1) were consumed by 
(a) Callosciurus notatus $n=348$



(b) Callosciurus caniceps $n=276$



(c) Sundasciurus lowii $n=180$



Fig. 2. Proportion of overall vertical space use for each squirrel species. 
(a) Callosciurus notatus $n=72$

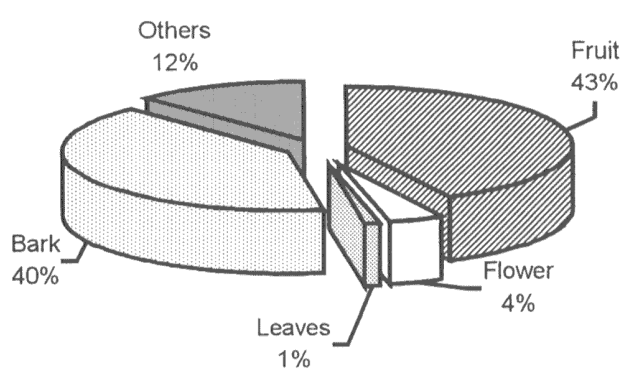

(b) Callosciurus caniceps $n=58$



(c) Sundasciurus lowii $n=24$

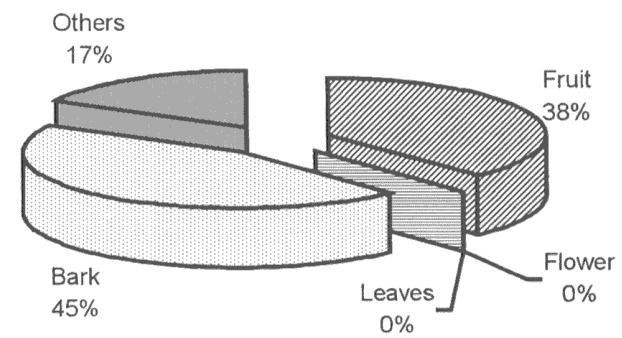

Fig. 3. Proportion of food items eaten by each squirrel species.

C. notatus. Bark of Pterocymbium javanicum was the most favored, followed by fruits of Piper adancum and Aglaia odoratissima. Callosciurus caniceps consumed 13 types of plants. These consisted mainly of the fruits of Artocarpus elasticus, leaves of Bambusa vulgaris and fruits of $P$. adancum and Ficus spp. (Table 1). Parts of six tree species were consumed by $S$. lowii (Table 1). Fruits of $P$. adancum and Cnarium spp. were eaten regularly, while bark was the major food item consumed from the other tree species (Table 1).

\section{Discussion}

A bimodal pattern of activity was apparent for each squirrel species, a finding consistent with results obtained for squirrels living sympatrically in other tropical areas (Emmons 1980; 
Table 1. List of tree species and foods eaten by $C$. notatus, $C$. caniceps and $S$. lowii. $F R=$ fruit; $F L=$ flower; $L F=$ leaf; $B K=$ bark; OFI = other food items.

\begin{tabular}{|c|c|c|c|c|c|}
\hline \multirow[b]{2}{*}{ No. } & \multirow[b]{2}{*}{ Family/species } & \multirow[b]{2}{*}{ Food items } & \multicolumn{3}{|c|}{$\%$ of feeding } \\
\hline & & & $\begin{array}{l}\text { C. notatus } \\
(n=72)\end{array}$ & $\begin{array}{l}\text { C. caniceps } \\
(n=58)\end{array}$ & $\begin{array}{r}S . \text { lowii } \\
(n=24)\end{array}$ \\
\hline 1. & $\begin{array}{l}\text { Araceae } \\
\text { Raphidophora lobii }\end{array}$ & LF & - & 1.7 & - \\
\hline 2. & $\begin{array}{l}\text { Burseraceae } \\
\text { Cnarium spp. }\end{array}$ & FR & - & - & 12.5 \\
\hline 3. & $\begin{array}{l}\text { Convolvulaceae } \\
\text { Merremia umbellata }\end{array}$ & FL & 1.4 & - & - \\
\hline $\begin{array}{l}4 . \\
5 .\end{array}$ & $\begin{array}{l}\text { Euphobiaceae } \\
\text { Drypetes laevis } \\
\text { Elateriospermum tapos }\end{array}$ & $\begin{array}{l}\text { BK } \\
\text { FR }\end{array}$ & $\begin{array}{l}5.6 \\
4.2\end{array}$ & $\overline{-}$ & $\overline{-}$ \\
\hline 6. & $\begin{array}{l}\text { Fagaceae } \\
\text { Quercus laponga }\end{array}$ & FR & - & 1.7 & - \\
\hline 7. & $\begin{array}{l}\text { Gramaneae } \\
\text { Bambusa vulgaris }\end{array}$ & $\begin{array}{l}\text { FL } \\
\text { LF }\end{array}$ & $\overline{-}$ & $\begin{array}{r}3.4 \\
17.2\end{array}$ & $\overline{-}$ \\
\hline 8. & $\begin{array}{l}\text { Lauraceae } \\
\text { Dehaasia spp. }\end{array}$ & BK & - & 4.2 & - \\
\hline $\begin{array}{r}9 . \\
10 .\end{array}$ & $\begin{array}{l}\text { Leguminaceae } \\
\text { Parkia javanicum } \\
\text { Sindora coriaceus }\end{array}$ & $\begin{array}{l}\text { BK } \\
\text { BK }\end{array}$ & $\begin{array}{l}1.4 \\
1.4\end{array}$ & $\overline{-}$ & $\overline{-}$ \\
\hline 11. & $\begin{array}{l}\text { Malvaceae } \\
\text { Hibiscus tiliaceus }\end{array}$ & FL & 1.4 & - & - \\
\hline $\begin{array}{l}12 . \\
13 . \\
14 . \\
15 .\end{array}$ & $\begin{array}{l}\text { Meliaceae } \\
\text { Aglaia odoratissima } \\
\text { Aglaia spp. } \\
\text { Dysoxylum papillosum } \\
\text { Sandoricum nervosum }\end{array}$ & $\begin{array}{l}\text { FR } \\
\text { BK } \\
\text { FL } \\
\text { FR }\end{array}$ & $\begin{array}{c}11.1 \\
2.8 \\
- \\
-\end{array}$ & $\begin{array}{l}- \\
\overline{1.7} \\
3.4\end{array}$ & $\begin{array}{l}- \\
\overline{-} \\
-\end{array}$ \\
\hline $\begin{array}{l}16 . \\
17 .\end{array}$ & $\begin{array}{l}\text { Moraceae } \\
\text { Artocarpus elasticus } \\
\text { Ficus spp. }\end{array}$ & $\begin{array}{l}\text { BK } \\
\text { FR } \\
\text { FR } \\
\text { LF }\end{array}$ & $\begin{array}{l}8.3 \\
4.2 \\
2.8 \\
1.4\end{array}$ & $\begin{array}{r}6.9 \\
19.0 \\
10.3 \\
-\end{array}$ & $\begin{array}{l}- \\
- \\
-\end{array}$ \\
\hline $\begin{array}{l}18 . \\
19 .\end{array}$ & $\begin{array}{l}\text { Piperaceae } \\
\text { Piper adancum } \\
\text { Piper spp. }\end{array}$ & $\begin{array}{l}\text { FR } \\
\text { LF }\end{array}$ & $\stackrel{12.5}{-}$ & $\begin{array}{r}10.3 \\
1.7 \\
\end{array}$ & 25.0 \\
\hline 20. & $\begin{array}{l}\text { Polygalaceae } \\
\text { Xanthophylum spp. }\end{array}$ & BK & - & - & 8.3 \\
\hline 21. & $\begin{array}{l}\text { Rubiaceae } \\
\text { Timonius spp. } \\
\text { Gardenia tubifera }\end{array}$ & $\begin{array}{l}\text { BK } \\
\text { BK }\end{array}$ & $\overline{-}$ & $\begin{array}{l}6.9 \\
-\end{array}$ & $\overline{8.3}$ \\
\hline $\begin{array}{l}23 . \\
24 .\end{array}$ & $\begin{array}{l}\text { Sapindaceae } \\
\text { Pometia pinnata } \\
\text { Xerospermum intermedium }\end{array}$ & $\begin{array}{l}\text { FR } \\
\text { FR }\end{array}$ & $\begin{array}{l}2.8 \\
4.2\end{array}$ & $\underline{-}$ & $\begin{array}{l}- \\
-\end{array}$ \\
\hline 25. & $\begin{array}{l}\text { Sterculiaceae } \\
\text { Pterocymbium javanicum }\end{array}$ & BK & 16.7 & 3.4 & 12.5 \\
\hline 26. & $\begin{array}{l}\text { Thymelaeaceae } \\
\text { Gonystylus maingayi }\end{array}$ & BK & 1.4 & - & - \\
\hline 27. & $\begin{array}{l}\text { Urticaceae } \\
\text { Villaebrunea rubescens }\end{array}$ & $\begin{array}{l}\text { BK } \\
\text { FL }\end{array}$ & $\begin{array}{l}2.8 \\
1.4\end{array}$ & $\overline{5.2}$ & $\overline{-}$ \\
\hline 28. & $\begin{array}{l}\text { Vernenaceae } \\
\text { Teijmanniodendron spp. }\end{array}$ & BK & - & - & 8.3 \\
\hline & & OFI & 12.5 & 6.9 & 16.7 \\
\hline
\end{tabular}


Whitten 1981). All three species reach a morning peak of activity at $0700 \mathrm{hrs}$, with a steady decline in activity by $0800 \mathrm{hrs}$. Activity was consistently low from 1100 to $1400 \mathrm{hrs}$ and began to increase from $1500 \mathrm{hrs}$ until reaching a second peak at $1800 \mathrm{hrs}$ for the two Callosciurus spp. and at $1600 \mathrm{hrs}$ for S. lowii. There was no obvious temporal niche segregation among the three species.

According to Aschoff (1963), a bimodal pattern is controlled by endogenous factors, which in Eurasian red squirrels, Sciurus vulgaris, appeared to be linked to the depletion of the stomach contents (Wauters and Dhondt 1987; Wauters et al. 1992). On the other hand, Thompson (1977) reported that environmental or external factors, especially temperature, play an important role in the determination of bimodal patterns during the summer in gray squirrels, Sciurus carolinensis. In the current study, activity levels for the three squirrel species were considerably low during the midday when the highest mean temperature $\left(30^{\circ} \mathrm{C}-\right.$ $31^{\circ} \mathrm{C}$ ) was recorded. Wauters and Dhondt (1987) proposed that squirrels that were active during periods of high ambient temperature would risk overheating.

Furthermore, Whitten (1981) suggested that predation might influence bimodal activity patterns in Callosciurus melanogaster in Siberut Island, Indonesia. The two Callosciurus spp. in the current study area were exposed to terrestrial predators (canids and felids) and aerial predators such as raptors (Tamura and Yong 1993). Generally, because diurnal raptors depend on eyesight to find prey, they require good light (Whitten 1981), whereas felids commonly hunt at dawn and dusk (Kavanau 1976). By being active when the diurnal raptors were less able to see and felids are less mobile, the squirrels may have greatly reduced the risk of predation.

A partly differential use of the multiple levels of forest strata is consistent with studies conducted by MacKinnon (1978), Emmons (1980) and Whitten (1981). Among the three squirrels in our study, $S$. lowii and $C$. caniceps were more restricted in vertical space use than C. notatus. These species concentrated mainly at lower tree heights especially S. lowii. Habitat preference is probably a factor that affects the use of vertical space by $S$. lowii, which is usually found in shrubby areas with few tall trees (Medway 1983). Habitat preference also likely affects the use of vertical space by $C$. notatus and $C$. caniceps. The former species is generalist in habitat use, using both shrubs and dense forests with tall trees, whereas the latter species is more common in shrubs (Tamura and Yong 1993). The distribution of food resources may be another factor affecting the use of vertical space by squirrels. For example, during fruiting seasons of Artocarpus elasticus, C. caniceps made more efforts to forage at the higher canopy levels than during the non-fruiting seasons.

Under a natural situation, the diet of squirrels depends on food availability, which varies according to habitat type (Gurnell 1987). In this study, C. notatus, which is a habitat generalist, had more chances to exploit numerous tree species than the other two squirrel species.

Both $C$. notatus and $C$. caniceps exploited a wide variety of food items, a behavior that is typical of this genus (Harrison 1954; MacKinnon 1978). On the other hand, S. lowii had a more specific diet, consuming high proportions of bark, similar to the reports from Siberut Island (Whitten and Whitten 1987). This might be a consequence of its selection of shrubdominated habitats (Medway 1983). Fruits (including seeds) were the major food item for all three squirrels species. This is consistent with reports for other tropical squirrels (MacKinnon 1978; Emmons 1980), neotropical squirrels (Glanz et al. 1982; Glanz 1984) and 
those living in temperate regions (Smith and Follmer 1972; Moller 1983). Most fruits and seeds selected by squirrels have high-energy contents (Grodzinski and Sawicka-Kapusta 1970; Smith and Follmer 1972). Leaves and flowers are less nutritious food resources, but they are probably eaten when fruits are scarce (Nichols 1958; Keith 1965; Emlen 1966; Smith 1968). Among northern squirrels, bark is a regular food item only for a short period in winter to early spring, when food (especially fruits) is scarce (Keith 1965).

Giller (1984) stated that if two closely related species coexisted, there should be some ecological differences between them in at least one niche dimension. In nature, however, niche overlap is a common phenomenon (Pianka 1974). Niche overlap refers to the use of similar resource types by two or more species (Abrams 1980) and therefore, is related to interspecific competition. Slobodchikoff and Schulz (1980) proposed that the intensity of competition depends on the amount of available resources, and that a high abundance of the required resources would result in two populations or species not competing to any significant extent. In tropical rain forests, flowers or fruits can be seen at any time of the year (Richards 1996). Therefore, primary food sources are available year-round, and if resources are not in short supply there might be no need for competition (Hulbert 1978).

In this study, niche overlap values for food type were as high as niche overlap values of vertical space and time. However, only a few tree species were utilized by all three squirrels. In other words, the three species of squirrel prefer different tree species as their food sources. Hence, differences in selection of tree species rather than food types such as flowers, leaves, and bark may be a major niche dimension which determined coexistence of squirrels in the study area. A similar situation was reported among tropical primates (Peres 1993; Guillotin and Dubost 1994) and birds (Fuentes 1994).

Acknowledgements: We thank the National Institute for Environmental Studies of Japan (Global Environment Research Program supported by Japan Environment Agency, grant no. E-2) for funding the research project. Special thanks to Dr. Noriko Tamura-Hayashi for her valuable comments and ideas throughout this project. Our thanks are also due to staffs of the University of Malaya Field Study Center; Mr. Mohd Kirwan, Mr. Bah Tera, Mr. Bah Dengui and Mr. Ismail Abu for giving us assistance throughout the study, and anonymous reviewers for valuable comments that helped us to further improve the manuscript.

\section{References}

Abrams, P. 1980. Some comments on measuring niche overlap. Ecology 61: 44-49

Adler, G. H. 1985. Habitat selection and species interaction: An experimental analysis with small mammal population. Oikos 45: 380-390.

Angelstam, P., Hansson, L. and Pehrsson, S. 1987. Distribution borders of field mice Apodemus: The importance of seed abundance and landscape composition. Oikos 50: 123-130.

Armitage, K. B. and Harris, K. S. 1982. Spatial patterning in sympatric populations of fox and gray squirrels. The American Midland Naturalist 108: 389-397.

Aschoff, J. C. 1963. Comparative physiology: Diurnal rhythms. Annual Review of Physiology 25: 561-600.

Douglass, R. J. 1976. Spatial interactions and microhabitat selections of two locally sympatric voles, Microtus montanus and Microtus pennsylvanicus. Ecology 57: 346-352.

Ducey, P. K., Schramm, K. and Cambry, N. 1994. Interspecific aggression between the sympatric salamanders, Ambystoma maculatum and Plethodon cinereus. The American Midland Naturalist 131: 320-329. 
Emlen, J. M. 1966. The role of time and energy in food preference. The American Naturalist 100: 611-617.

Emmons, L. H. 1980. Ecology and resource partitioning among nine species of African rain forest squirrels. Ecological Monographs 50: 31-54.

Feinsinger, P., Spears, E. E. and Poole, R. W. 1981. A simple measure of niche breadth. Ecology 62: 27-32.

Fuentes, M. 1994. Diets of fruit-eating birds: What are the causes of interspecific differences? Oecologia 97: 134142.

Giller, P. S. 1984. Community Structure and the Niche. Chapman and Hall, London, $176 \mathrm{pp}$.

Glanz, W. E. 1984. Food and habitat use by two sympatric Sciurus species in central Panama. Journal of Mammology 65: 342-347.

Glanz, W. E., Thorington Jr, R. W., Giacalone-Madden, J. and Heaney, L. R. 1982. Seasonal food use and demographic trends in Sciurus granatensis. In (E. G. Leigh Jr., A. S. Rand and D. M. Windsor, eds.) The Ecology of a Tropical Forest: Seasonal Rhythms and Long-term Changes. Pp. 239-252. Smithsonian Press, Washington.

Grodzinski, W. and Sawicka-Kapusta, K. 1970. Energy values of tree-seeds eaten by small mammals. Oikos 21: 52-58.

Guillotin, M. and Dubost, G. 1994. Food niche and food competition among the three major primate species of French Guinea. Journal of Zoology (London) 233: 551-579.

Gurnell, J. 1987. The Natural History of Squirrels. Christopher Helm, London, $201 \mathrm{pp.}$

Harrison, J. L. 1954. The natural food of some rats and other mammals. Bulletin of the Raffles Museum 25: 157165.

Hulbert, S. T. 1978. The measurement of niche overlap and some relatives. Ecology 59: 67-77.

Kavanau, L. 1976. Animals in a twilight world. New Scientist 71: 574-576.

Keith, J. O. 1965. The abert squirrel and its dependence on penderosa pine. Ecology 46: 150-163.

Lacher Jr, T.E. and Alho, C. J. R. 1989. Microhabitat use among small mammals in the Brazilian Pantanal. Journal of Mammology 70: 396-401.

MacKinnon, K.S. 1978. Stratification and feeding differences among Malayan squirrels. Malayan Nature Journal 30: 593-608.

Martin, P. and Bateson, P. 1987. Measuring Behaviour: An Introductory Guide. Cambridge University Press, Cambridge, $200 \mathrm{pp}$.

Medway, L. 1983. The Wild Mammals of Malaya (Peninsular Malaysia) and Singapore (2nd Edition). Oxford University Press, Oxford, $131 \mathrm{pp}$.

Moller, H. 1983. Foods and foraging behaviour of red (Sciurus vulgaris) and grey (Sciurus carolinensis) squirrels. Mammal Review 13: 81-98.

Mullican, T. R. and Baccus, J. T. 1990. Horizontal and vertical movements of the white-ankled mouse (Peromyscus pectoralis) in central Texas. Journal of Mammology 71: 378-381.

Nichols, J. T. 1958. Food habits and behaviour of the grey squirrels. Journal of Mammalogy 39: 376-380.

Peres, C. A. 1993. Diet and feeding ecology of saddle back (Saguinus fuscicollis) and mouthache (S. mystax) tamarins in an Amazonian Terra Firme forest. Journal of Zoology (London) 230: 567-592.

Pianka, E. R. 1973. The structure of lizards communities. Revision of Ecological Systematic 4: 53-74.

Pianka, E. R. 1974. Evolutionary Ecology. Harper and Row, New York, 356 pp.

Richards, P. W. 1996. The Tropical Rain Forest (2nd edition). Cambridge University Press, Cambridge, 575 pp.

Riege, D. A. 1991. Habitat specialization and social factors in distribution of red and grey squirrels. Journal of Mammalogy 72: 152-162.

Schoener, T. W. 1974. Resource partitioning in ecological communities. Science 185:27-39.

Sheppard, D. H. 1971. Competition between two chipmunk species (Eutamias). Ecology 52: 320-329.

Slobodchikoff, C. N. and Schulz, W. C. 1980. Measures of niche overlap. Ecology 61: 1051-1055.

Smith, C. C. 1968 . The adaptive nature of social organization in the genus of tree squirrels Tamiasciurus. Ecological Monographs 39: 31-63.

Smith, C. C. and Follmer, D. 1972. Food preferences of squirrels. Ecology 53: 82-91.

Tamura, N. 1993. Role of sound communication in mating of Malaysian Callosciurus (Sciuridae). Journal of Mammology 74: 468-476.

Tamura, N. and Yong, H.S. 1993. Vocalizations in response to predators in three species of Malaysian Callosciurus (Sciuridae). Journal of Mammalogy 74: 703-714. 
Thompson, D. C. 1977. Diurnal and seasonal activity of the grey squirrel (Sciurus carolinensis). Canadian Journal of Zoology 55: 1185-1189.

Wauters, L. and Dhondt, A. A. 1987. Activity budget and foraging behaviour of the red squirrels Sciurus vulgaris (Linnaeus, 1758) in a coniferous habitat. Sanderdruck Aus Z.F. Saugetierkunde BD 52: 341-353.

Wauters, L., Swinnen, C. and Dhondt, A. A. 1992. Activity budget and foraging behaviour of red squirrels (Sciurus vulgaris) in coniferous and deciduous habitats. Journal of Zoology (London) 227: 71-86.

Whitten, J. E. J. 1981. Ecological separation of three diurnal squirrels in tropical rainforest on Siberut Island, Indonesia. Journal of Zoology (London) 193: 405-420.

Whitten, J. E. J. and Whitten, A. J. 1987. Analysis of bark eating in a tropical squirrels. BIOTROPICA 19: 107115.

Received 12 July 2000. Accepted 9 October 2001. 